TOMASZ PRZYBYEA

MichAє KLICHOWSKI

Uniwersytet im. Adama Mickiewicza

w Poznaniu

\title{
CODZIENNE OPERACJE ARYTMETYCZNE A PROBLEM KOSZTÓW PODWÓJNEGO ZADANIA: RAPORT Z EKSPERYMENTU BEHAWIORALNEGO KONTROLOWANEGO ELEKTROENCEFALOGRAFEM
}

\begin{abstract}
Przybyła Tomasz, Klichowski Michał, Codzienne operacje arytmetyczne a problem kosztów podwójnego zadania: raport z eksperymentu behawioralnego kontrolowanego elektroencefalografem [Everyday Mental Calculations and Dual-Task Costs: Evidences from a Behavioral Experiment Supported by EEG]. Studia Edukacyjne nr 49, 2018, Poznań 2018, pp. 145-155. Adam Mickiewicz University Press. ISSN 1233-6688. DOI: $10.14746 /$ se.2018.49.9
\end{abstract}

Very recent studies show that a cognitive-motor interference can expose people not only to a motor danger but also weaken their cognitive capabilities. This effect is called the dual-task cost. One of the most popular examples of it nowadays is the smartphone use while walking, which is well examined. Yet, there are no studies that would analyse to what extent the other high-popular dual-task situation - shopping at the supermarket, weakens cognitive processes. To shed some light on this issue, we investigated a behavioral experiment on everyday mental calculations. Methods: Twenty mathematically-educated adults took part in this study. We used stimuli in the form of shop labels. The participant's task was to add two prices or state the price after a discount. They carried out the tasks by turns, either by standing (single-task) or walking with a shopping basket (dual-task). EEG controlled level of their attention. Results: We found that a cognitive-motor interference do not affected the everyday mental calculations. But, such familiar mental arithmetic as calculating prices after discounts was frighteningly difficult for the participants. Conclusions: While our finding does not confirm the occurrence of dual-task costs in everyday mental calculations, it has profound consequences for a mathematical education, which effects turn out to be useless in real life.

Key words: mental arithmetic, cognitive-motor interference, mathematical education, shopping at the supermarket

\section{Wprowadzenie}

W medycynie, psychologii i pedagogice tradycyjnie postrzegano aktywność poznawczą jako poniekąd odseparowaną od aktywności fizycznej. 
W ostatnich latach zgromadzono jednak dowody na istnienie interferencji poznawczo-motorycznej (cognitive-motor interference) ${ }^{1}$. Naukowcy zauważyli, że obszary mózgu odpowiedzialne za kontrolę poznawczą (cognitive control) są aktywowane podczas wykonywania, jak się wydawało zautomatyzowanych, ruchów, na przykład podczas chodu ${ }^{2}$. Oznacza to, że nawet proste aktywności fizyczne wymagają kontroli na poziomie poznawczym, a zatem nie są automatyczne i zmuszają do pewnego elementarnego skoncentrowania ${ }^{3}$.

Konsekwencją takiej poznawczo-motorycznej interferencji jest to, że podczas wykonywania podwójnego (poznawczo-motorycznego) zadania (dual-task), osłabieniu ulega wydajność wykonania jednej lub obu czynności ${ }^{4}$ Na przykład, kiedy podczas spaceru zaczynamy konwersować o jakimś logicznym problemie, prędkość naszego chodu natychmiast spada (lub zmniejszeniu ulega długość kroków) ${ }^{5}$. Dzieje się tak dlatego właśnie, że uwaga kontroluje motoryczne bezpieczeństwo ${ }^{6}$, a kiedy jej zasoby zaczynają być angażowane w zadanie poznawcze ${ }^{7}$, mózg - nie mogąc efektywnie zabezpieczać naszej mobilności - spowalnia chód, czyniąc go mniej niebezpiecznym ${ }^{8}$. I w drugą stronę: Kiedy wykonując jakieś zadanie intelektualne, zaczynamy angażować się również w aktywność fizyczną, wydajność realizacji tego poznawczego zadania natychmiast spada9. Takie zjawisko nazywane jest kosztami podwój-

1 D.A. Wajda, R.W. Motl, J.J. Sosnoff, Dual task cost of walking is related to fall risk in persons with multiple sclerosis, Journal of the Neurological Sciences, 2013, 335, s. 160.

2 M. Bakker i in., Cerebral correlates of motor imagery of normal and precision gait, NeuroImage, 2008, 41, s. 998-1010; S. Huda i in., Cortical activation during foot movements. II. Effect of movement rate and side, Neuroreport, 2008, 19, s. 1573-1577; K. Iseki i in., Neural mechanisms involved in mental imagery and observation of gait, NeuroImage, 2008, 41, s. 1021-1031; C. Rosano i in., Gait measures indicate underlying focal gray matter atrophy in the brain of older adults, Journals of Gerontology Series A-Biological Sciences and Medical Sciences, 2008, 63, s. 1380-1388; S. Francis i in., fMRI analysis of active, passive and electrically stimulated ankle dorsiflexion, NeuroImage, 2009, 44, s. 469-479; T. Harada i in., Gait capacity affects cortical activation patterns related to speed control in the elderly, Experimental Brain Research, 2009, 193, s. 445-454.

${ }_{3}$ M. Woollacott, A. Shumway-Cook, Attention and the control of posture and gait: a review of an emerging area of research, Gait \& Posture, 2002, 16, s. 1, 13.

${ }^{4} \mathrm{P}$. Yuan i in., Increased brain activation for dual tasking with 70-days head-down bed rest, Frontiers in Systems Neuroscience, 2016, 10, s. 2.

${ }^{5}$ E. Al-Yahya i in., Cognitive motor interference while walking: a systematic review and meta-analysis, Neuroscience \& Biobehavioral Reviews, 2011, 35, s. 716-717.

6 L.S. Nagamatsu i in., Increased cognitive load leads to impaired mobility decisions in seniors at risk for falls, Psychology and Aging, 2011, 26, s. 253

7 M. Bonato i in., Dual-tasks induce awareness deficits for the contralesional hemispace, Frontiers in Human Neuroscience, 2012, 129, s. 1.

${ }^{8}$ K. Pothier i in., Multiple object tracking while walking: similarities and differences between young, young-old, and old-old adults, Journals of Gerontology Series B: Psychological Sciences and Social Sciences, 2014, 70, s. 840-841.

9 N. Takeuchi i in., Parallel processing of cognitive and physical demands in left and right prefrontal cortices during smartphone use while walking, BMC Neuroscience, 2016, 17, s. 2. 
nego zadania (the dual-task cost) ${ }^{10}$. Koszty te są tym większe, im zadanie poznawcze jest trudniejsze ${ }^{11}$ lub aktywność fizyczna jest intensywniejsza ${ }^{12}$.

Jedną z najpowszechniejszych współcześnie sytuacji, w której jesteśmy narażeni na ponoszenie znacznych kosztów podwójnego zadania jest używanie smartfona podczas chodu ${ }^{13}$. Potwierdzają to zarówno statystyki medyczne, ukazujące wzrastającą liczbę wypadków z udziałem pieszych klikających w ekran telefonu komórkowego ${ }^{14}$, jak i wyniki najnowszych badań ${ }^{15}$. Inną taką sytuacją wydają się zakupy w supermarkecie. Tu, spacerując ze sklepowym koszykiem, zobligowani jesteśmy do dokonywania licznych obliczeń matematycznych, na przykład do sumowania cen (np. 2,50 zł + 3,50 zł) czy wyliczania ceny produktu po obniżce (np. 8,80 zł - 50\%). I choć wiemy, że praksja jest silnie powiązana $\mathrm{z}$ przetwarzaniem liczb ${ }^{16}$, dotychczas nie zbadano tego, czy koszty podwójnego zadania powstają w sytuacji takiej codziennej („sklepowej”) arytmetyki. Aby to sprawdzić, przeprowadziliśmy eksperyment, w którym badani sumowali ceny lub obliczali promocyjną cenę, czasem stojąc przy regale sklepowym, a czasem spacerując ze sklepowym koszykiem. Podczas tych zadań kontrolowaliśmy koncentrację uczestników jednoelektrodowym encefalografem. Wyniki tego eksperymentu nie tylko rzucają nowe światło na koncepcję kosztów podwójnego zadania, ale także na kondycję matematycznej edukacji. Nasz eksperyment pokazuje bowiem, że koncepcja ta jest w pewnym sensie „przereklamowana” oraz że dorosłe (i co ważne: matematycznie wyedukowane) osoby słabo radzą sobie z codzienną arytmetyką, a w konsekwencji znacząco „przeceniają” korzystność supermarketowych promocji.

${ }^{10}$ P. Yuan i in., Increased brain activation, s. 2.

${ }_{11}$ K. Pothier i in., Multiple object tracking while walking, s. 725.

12 Tamże, s. 844-846.

${ }^{13}$ N. Takeuchi i in., Parallel processing of cognitive and physical demands, s. 1-2.

${ }_{14}$ M. Yamada i in., Using a smartphone while walking: a measure of dual-tasking ability as a falls risk assessment tool, Age and Ageing, 2011, 40, s. 516-519.

${ }^{15}$ L.S. Nagamatsu i in., Increased cognitive load leads, s. 254; M. Klichowski, Learning in CyberParks. A theoretical and empirical study, Poznań 2017, s. 165-192.

${ }^{16}$ M. Klichowski, G. Króliczak, Numbers and functional lateralization: a visual half-field and dichotic listening study in proficient bilinguals, Neuropsychologia, 2017, 100, s. 93-109; T. Przybyła, M. Klichowski, Does cyberspace increase young children's numerical performance? A brief overview from the perspective of cognitive neuroscience, [w:] Świat małego dziecka. Przestrzeń instytucji, cyberprzestrzeń i inne przestrzenie dzieciństwa, red. H. Krauze-Sikorska, M. Klichowski, Poznań 2017, s. 425-444; T. Przybyła, M. Klichowski, „Cyfrowe liczby”: Przykłady narzędzi ICT służacych kształtowaniu kompetencji matematycznych ucznia poprzez stymulacje praksji, [w:] Psychoedukacyjne problemy młodzieży, czyli jak być świadomym wychowawca, Poznań 2018, s. 56-64; odnośnie praksji patrz: M. Buchwald, L. Przybylski, G. Króliczak, Decoding Brain States for Planning Functional Grasps of Tools: A Functional Magnetic Resonance Imaging Multivoxel Pattern Analysis Study, Journal of the International Neuropsychological Society, FirstView, 2018; G. Króliczak i in., Ręczność, praksja i język: nowe spojrzenie na delikatna triadę, Polskie Forum Psychologiczne, 2018, 23, s. 22-34. 


\section{Metody}

\section{Uczestnicy}

Dwudziestu zdrowych ochotników (w tym 16 kobiet) w wieku od 20 do 22 lat (średnia $=20,75)$ wzięło udział $\mathrm{w}$ badaniu $(N=20)$. Przed badaniem przedstawiliśmy każdemu z nich szczegółowy przebieg eksperymentu. Wszyscy uczestnicy wyrazili pisemną zgodę na udział w badaniu. Wzrok każdego z badanych był normalny lub skorygowany do normalnego. Trzy osoby były leworęczne (w tym 1 mężczyzna). Wszyscy badani odbyli pełen (12- lub 13-letni) cykl edukacji matematycznej, którego zwieńczeniem było zdanie matury z matematyki na poziomie co najmniej podstawowym.

\section{Bodźce}

Użyliśmy wysokiej rozdzielczości grafik $\mathrm{w}$ formacie .PNG przedstawiających 20 par etykiet sklepowych, na których znajdowały się ceny w formie $X \underline{X X}$ (przykłady tych bodźców zostały ukazane na rycinie 1A) oraz 20 takich etykiet sklepowych wraz z wartością obniżki $(-25 \%,-50 \%$ albo $-75 \%$; przykłady tych bodźców zostały ukazane na rycinie 1B). W przypadku pierwszej grupy bodźców zadaniem badanego było podanie sumy dwóch cen, a w kontekście drugiej - podanie ceny po obniżce.
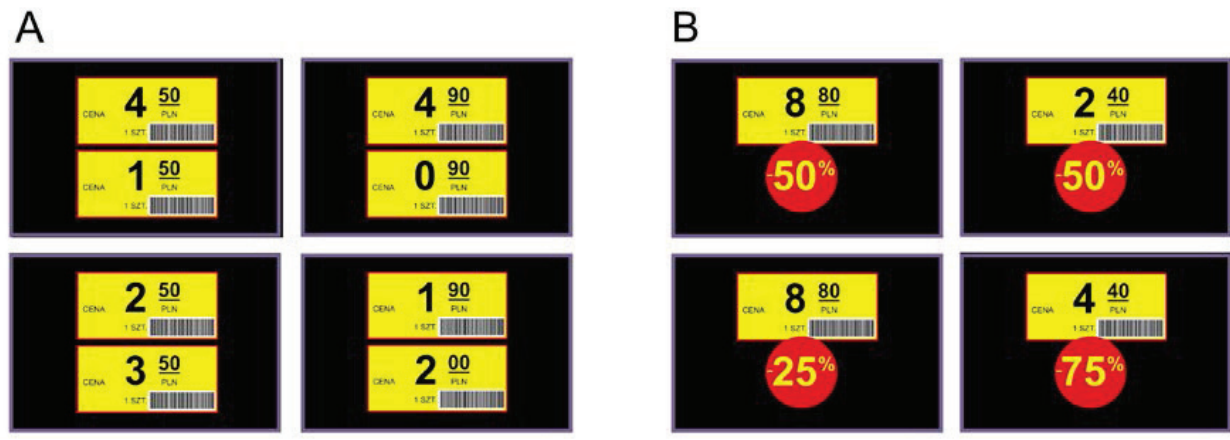

Ryc. 1. Przykłady bodźców użytych w eksperymencie

(A) Przykłady par etykiet sklepowych - zadaniem badanego było podanie sumy dwóch cen.

(B) Przykłady etykiety sklepowej z informacją o obniżce - zadaniem badanego było podanie ceny po obniżce

\section{Procedura i aparatura}

Eksperyment zaprojektowaliśmy w programie SuperLab for Mac 4.5 (Cedrus Corporation, San Pedro, CA, USA) i kontrolowaliśmy go poprzez 
komputer MacBook Pro 2,7 GHz (Apple Inc., Cupertino, CA, USA). Bodźce wyświetlane były na 22-calowym monitorze Samsung (Seoul, South Korea), umieszczonym w odległości $114 \mathrm{~cm}$ od badanego. Ekspozycja danego bodźca trwała do momentu udzielenia odpowiedzi, jednak nie dłużej niż 6 sekund. Każdy bodziec poprzedzał punkt fiksacji (miejsce, w które należy patrzeć) w postaci białego krzyżyka na czarnym tle, wyświetlany przez 500 milisekund. Badani podawali odpowiedzi słownie, a my kontrolowaliśmy ich poprawność. Czasy reakcji rejestrował natomiast SV-1 Smart Voice Key (Cedrus Corporation, San Pedro, CA, USA). Po odpowiedzi badanego lub po pełnej ekspozycji bodźca uruchamiany był interwał w formie czarnego ekranu, trwający 500 milisekund. Po interwale rozpoczynała się kolejna próba (ryc. 2).
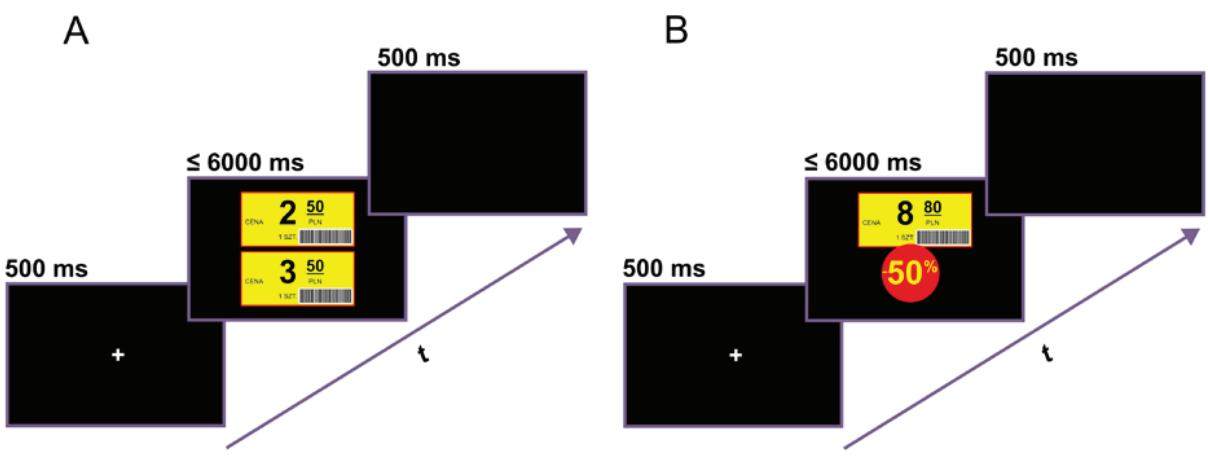

Ryc. 2. Struktura próby

(A) Każda próba w zadaniu polegającym na podawaniu sumy dwóch cen rozpoczynała się trwającą 500 milisekund ekspozycją punktu fiksacji. Następnie wyświetlana była para etykiet sklepowych, która znikała po udzieleniu odpowiedzi lub po 6000 milisekund. Po ekspozycji bodźca uruchamiany był interwał w formie czarnego ekranu. Po interwale rozpoczynała się kolejna próba. Podczas połowy prób badany symulował chód. (B) Każda próba w zadaniu polegającym na podawaniu ceny po obniżce rozpoczynała się trwającą 500 milisekund ekspozycją punktu fiksacji. Następnie wyświetlana była etykieta sklepowa wraz z wartością obniżki, które znikały po udzieleniu odpowiedzi lub po 6000 milisekund. Po ekspozycji bodźca uruchamiany był interwał w formie czarnego ekranu. Po interwale rozpoczynała się kolejna próba. Podczas połowy prób badany symulował chód

Podczas eksperymentu badany zajmował wygodną pozycję na specjalnym rotorze neurologicznym RD-1 Rotor for Lower Limb Exercise (Meden-Inmed, Koszalin, Polska), umożliwiającym symulowanie chodu bez ryzyka upadku $^{17}$. Co 10 prób następowała zmiana: badany zaczynał lub przestawał symulować chód. Podczas prób z symulowaniem chodu, uczestnicy trzymali w ręce koszyk sklepowy wypełniony produktami; przed pozostałymi próbami odkładali koszyk na ziemię. Do rotora zamontowany był licznik prędko-

${ }_{17}$ T. Fujiwara, M. Liu, N. Chino, Effect of pedaling exercise on the hemiplegic lower limb, American Journal of Physical Medicine \& Rehabilitation, 2003, 82, s. 357-363. 
ści DC4 S (b'Twin, Villeneuve d'Ascq, France). Przed badaniem każda osoba uczyła się utrzymywania tempa charakterystycznego dla spaceru po sklepie (4.0-5.0 km/h) oraz odbyła sesję treningową, w której mogła wykonać zadania analogiczne do eksperymentalnych.

Eksperyment składał się z dwóch bloków. W każdym z nich prezentowana była inna grupa bodźców. W każdym bloku było 20 prób, w tym 10 prób z symulowaniem chodu (podwójne zadanie). Kolejność bloków i typów zadań była pseudozrandomizowana.

\section{Kontrola koncentracji}

Aby kontrolować poziom koncentracji badanych, na ich głowach umieściliśmy jednoelektrodowy elektroencefalograf MindWave Mobile EEG (NeuroSky, Silicon Valley, CA, USA), służący do monitorowania fal ludzkiego mózgu $^{18}$. Elektroda umieszczana była na podstawowej pozycji Fp1 ${ }^{19}$ (czoło), a elektroda referencyjna w formie klipsa na pozycji A1 (ucho) ${ }^{20}$. Wykorzystaliśmy oparty głównie na falach beta (> 14 Hz) algorytm eSense Attention Meter (NeuroSky, Silicon Valley, CA, USA), poprzez który określaliśmy poziom (w skali od 0 do 100) koncentracji na wykonywanym zadaniu poznawczym. Wartości mniejsze niż 40 oznaczają tu koncentrację obniżoną, a większe od 60 podwyższoną; wartości między 40 a 60 stanowiły stan koncentracji neutralnej (baseline) $^{21}$. Dane z MindWave Mobile EEG rejestrowaliśmy poprzez oprogramowanie NeuroSky Recorder for iOS (NeuroSky, Silicon Valley, CA, USA) z użyciem iPhone 6s Plus (Apple Inc., Cupertino, CA, USA). Urządzenia te komunikowały się poprzez bluetooth.

\section{Analiza danych}

Głównymi zmiennymi zależnymi były różnice w poprawności odpowiedzi, czasach odpowiedzi (dla tego samego bodźca) i poziomie koncentracji, między zadaniem pojedynczym i podwójnym. Przyjęty poziom istotności wynosił $a=0,05$. Wszystkie analizy statystyczne zostały przeprowadzone z uży-

${ }^{18}$ J.C.Y. Sun, K.P.C. Yeh, The effects of attention monitoring with EEG biofeedback on university students' attention and self-efficacy: the case of anti-phishing instructional materials, Computers \& Education, 2017, 106, s. 76.

${ }^{19}$ M. Abo-Zahhad, S.M. Ahmed, S.N. Abbas, A new multi-level approach to EEG based human authentication using eye blinking, Pattern Recognition Letters, 2016, 82, s. 217-218.

${ }^{20}$ Tamże.

${ }^{21}$ W. Salabun, Processing and spectral analysis of the raw EEG signal from the MindWave, Przegląd Elektrotechniczny, 2014, 90, s. 169. 
ciem IBM SPSS Statistics for Mac w wersji 24 (IBM Corp., Armonk, NY, USA) na komputerze iMac 1,4 GHz (Apple Inc., Cupertino, CA, USA). Wykonaliśmy dwie (dla poprawności odpowiedzi i czasów reakcji) wieloczynnikowe analizy wariancji $(2 \times 2)$ dla powtarzanych pomiarów (rm-ANOVA) z następującymi czynnikami wewnątrzobiektowymi: typ operacji arytmetycznej (dodawanie dwóch cen lub obliczanie ceny po obniżce) oraz typ zadania (pojedyncze lub podwójne). Kiedy było to konieczne, zastosowaliśmy test post-hoc Bonferroniego (Bf). Aby porównać poziomy koncentracji, użyliśmy testu $t$-Studenta dla prób zależnych oraz analizy korelacji. Dla ukazania wielkości efektu podajemy wartość cząstkowego Eta kwadrat (pๆ2) wraz z obserwowaną mocą $(O P)$.

\section{Wyniki}

\section{Poprawność i szybkość wykonania zadania}

Analizując poprawność obliczeń arytmetycznych dokonywanych przez naszych badanych, jednoznacznie stwierdziliśmy, iż obliczanie ceny po obniżce było dla nich trudniejsze od sumowania dwóch cen (średnia różnica $\left.=16 \%, F_{(1,19)}=28,7, p<0,001, p \eta 2=0,60, O P=1\right)$. Jak pokazuje rycina $3 \mathrm{~A}$, nie zaobserwowaliśmy jednak istotnych różnic pomiędzy poprawnością obliczeń dokonywanych stojąc a poprawnością tych realizowanych spacerując (wszystkie $p>0,05$ ).
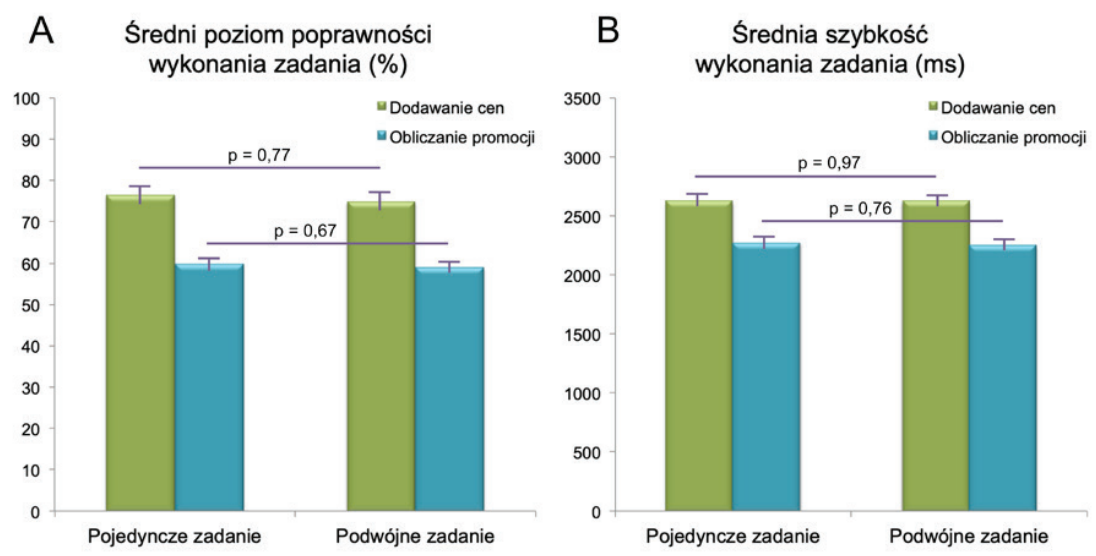

Ryc. 3. Poprawność i szybkość wykonania zadania

(A) Nie zaobserwowaliśmy istotnych różnic pomiędzy poprawnością obliczeń dokonywanych stojąc (pojedyncze zadanie) a poprawnością tych realizowanych spacerując (podwójne zadanie). (B) Analogicznie, nie zaobserwowaliśmy istotnych różnic pomiędzy szybkością obliczeń dokonywanych stojąc a szybkością tych realizowanych spacerując. Słupki błędów ukazują błędy standardowe średniej 
Analogicznie było w przypadku czasów wykonania zadania. Choć stwierdziliśmy, że badani szybciej obliczali ceny po obniżce, w porównaniu ze sumowaniem dwóch cen (średnia różnica $=358$ milisekund, $F_{(1,19)}=9,2$, $p<0,01, p \eta 2=0,33, O P=0,82)$, tempa wykonania tych operacji - jak pokazuje rycina $3 \mathrm{~B}$ - nie różnicowało to, czy były one realizowane $\mathrm{w}$ połączeniu $\mathrm{z}$ chodem (podwójne zadanie), czy też nie (wszystkie $p>0,05)$.

\section{Koncentracja podczas wykonania zadania}

Średni poziom skoncentrowania badanych był taki sam dla zadania pojedynczego i podwójnego $\left(t_{(19)}=-0,51, p=0,62\right.$, rycina $\left.4 \mathrm{~A}\right)$, co nie dziwi, zważywszy, że poprawność i szybkość były tu także analogiczne. Jak pokazuje rycina $4 \mathrm{~B}$, większość badanych wykonywała zadania utrzymując neutralny poziom koncentracji (wartości od 40 do 60 ) lub poziom podwyższony (od 60 wzwyż). Zaobserwowaliśmy silne skorelowanie tych danych $(p<0,01)$, co wskazuje, że osoby utrzymujące dany poziom koncentracji w zadaniu pojedynczym reprezentowały go także w zadaniu podwójnym.
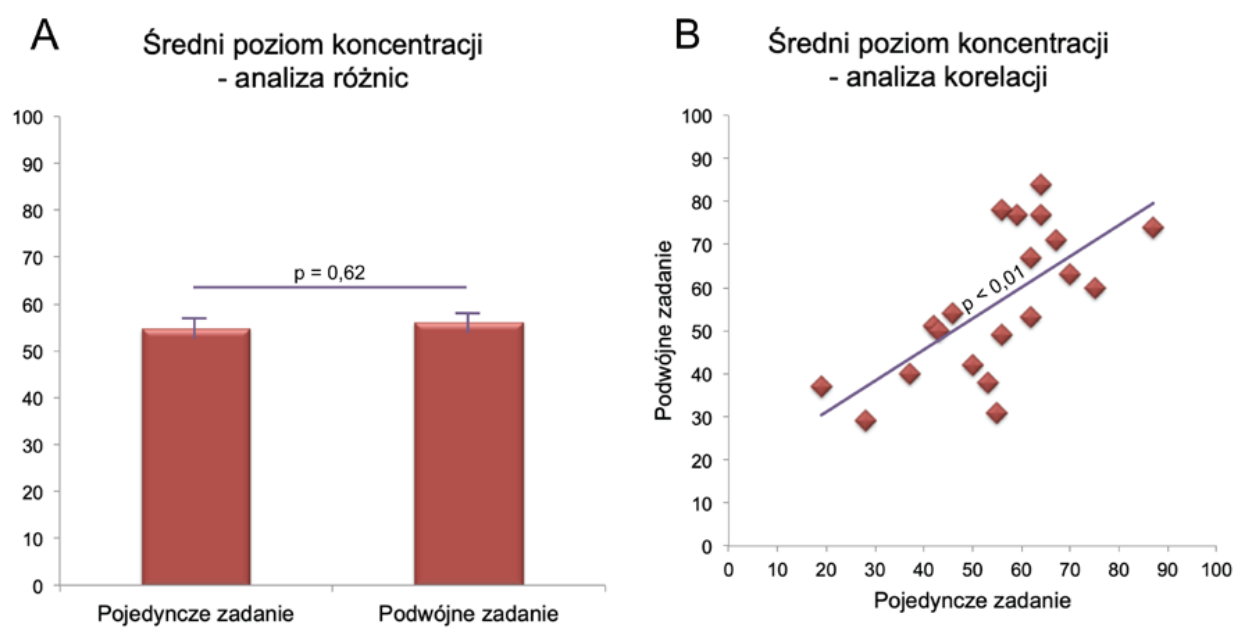

Ryc. 4. Koncentracja podczas wykonania zadania

(A) Średnie poziomy koncentracji podczas zadania pojedynczego i podwójnego nie różnią się od siebie. Słupki błędów ukazują błędy standardowe średniej. (B) Poziomy koncentracji podczas zadania pojedynczego i podwójnego są silnie skorelowane. Ukazano także linię trendu 


\section{Typy błędów w wykonaniu zadania}

Średnia poprawność wszystkich obliczeń matematycznych w obu badanych warunkach wynosi $67,62 \%$. Dla sumowania dwóch cen sięga ona jednak wartości $75,75 \%$, a dla obliczania ceny po obniżce już tylko 59,5\%. Oznacza to, że badani przy obliczaniu ponad $40 \%$ promocyjnych cen nie potrafili podać prawidłowej wartości. Co ciekawe, większość błędnych cen przez nich podawanych (oprócz sytuacji ewidentnej pomyłki, np. kiedy dla operacji 8,60 PLN - 75\%, badany podawał 6 PLN, zamiast 2,15 PLN) była zaniżona, a więc osoby te zawyżały wielkość obniżki. Przykłady tego typu błędów przedstawiamy w tabeli 1 .

Tabela 1

Przykłady błędów w obliczaniu ceny po obniżce

\begin{tabular}{|c|c|c|c|}
\hline $\begin{array}{c}\text { Operacja } \\
\text { matematyczna }\end{array}$ & Poprawny wynik & \multicolumn{2}{|c|}{ Podany wynik } \\
\hline 4,20 PLN - 25\% & 3,15 PLN & 2,1 PLN & 1,1 PLN \\
\hline 8,20 PLN - 25\% & 6,15 PLN & 6,05 PLN & 4,1 PLN \\
\hline 8,40 PLN - 25\% & 6,3 PLN & \multicolumn{2}{|c|}{ 6,1 PLN } \\
\hline 8,60 PLN - 25\% & 6,45 PLN & \multicolumn{2}{|c|}{ 6,15 PLN } \\
\hline 4,40 PLN - 50\% & 2,2 PLN & \multicolumn{2}{|c|}{ 1,2 PLN } \\
\hline 4,90 PLN - 50\% & 2,45 PLN & \multicolumn{2}{|c|}{ 2,3 PLN } \\
\hline 4,60 PLN - 75\% & 1,15 PLN & \multicolumn{2}{|c|}{ 1,1 PLN } \\
\hline 4,80 PLN - 75\% & 1,2 PLN & \multicolumn{2}{|c|}{ 1,1 PLN } \\
\hline 8,20 PLN - 75\% & 2,05 PLN & \multicolumn{2}{|c|}{ 1,1 PLN } \\
\hline
\end{tabular}

\section{Dyskusja}

Nasz eksperyment pokazuje, że efektywność obliczeń matematycznych wykonywanych w supermarkecie nie ulega osłabieniu w sytuacji poznawczo-motorycznej interferencji, a więc kiedy ary tmetyka ta łączona jest z aktywnością fizyczną - spacerem między sklepowymi regałami. Zarówno skuteczność tych mentalnych operacji, jak i poziom koncentracji na nich nie zmienia się bowiem, kiedy jednostka zaczyna poruszać się po sklepie. Jednakże, wśród uczestników naszego badania poziom wykonania operacji arytmetycznych jest w obu przypadkach (pojedynczego lub podwójnego zadania) niezwykle niski, zwłaszcza w kontekście obliczania ceny po promocji. Nasi badani często 
podawali cenę zbyt niską, a więc postrzegali obniżkę jako wyższą, niż jest ona w rzeczywistości. Wydaje się więc, iż pomimo że zakupy w supermarkecie nie generują "dodatkowych" kosztów, wynikających ze zmuszenia klienta do poznawczo-motorycznej interferencji w formie spaceru ze sklepowym koszykiem, supermarketowe promocje zwodzą procesy poznawcze młodych, matematycznie wyedukowanych ludzi, zniekształcając realny koszt ich zakupów.

\section{Brak dodatkowych kosztów zakupów w supermarkecie}

To, że w naszym badaniu połączeniu codziennych obliczeń matematycznych z aktywnością fizyczną nie towarzyszyło osłabienie poziomu wykonania tych operacji, wytłumaczyć można odwołując się do wyników badań nad korelacją wysokości kosztów podwójnego zadania i wiekiem danej osoby. Okazuje się bowiem, że koszty te radykalnie wzrastają, kiedy organizm zaczyna podlegać procesom już wczesnego starzenia ${ }^{22}$. Co więcej, koszty podwójnego zadania są równie wysokie (jak u osób starzejących się) u dzieci i nastolatków ${ }^{23}$. Funkcja wieku dla teorii kosztów podwójnego zadania ma więc kształt litery „ $\mathrm{U}^{\prime}$. Oznacza to, że koszty te są najniższe dla młodych dorosłych (late adolescents) ${ }^{24}$, a nimi byli właśnie nasi badani.

Choć więc standardem podstawowych eksperymentów behawioralnych jest badanie młodych dorosłych ${ }^{25}$, w przyszłych badaniach należy uwzględnić dzieci, młodzież i osoby starsze od młodych dorosłych. Dopiero wtedy możliwe będzie rozstrzygnięcie tego, w jakim stopniu teoria kosztów podwójnego zadania odnosi się (lub nie odnosi się wcale) do supermarketowych obliczeń matematycznych.

\section{Przeszacowywanie obniżek}

Poprawność wykonania codziennych obliczeń matematycznych zaobserwowana w naszym badaniu budzi zdziwienie, zwłaszcza w kontekście obliczania cen po obniżce. Nasi badani potrafili poprawnie wykonać tylko

${ }^{22}$ K. Pothier i in., Multiple object tracking while walking, s. 844-845; E. Al-Yahya i in., Cognitive motor interference while walking, s. 720-723.

${ }^{23}$ P. Hagmann-von Arx $\mathrm{i}$ in., Walking in school-aged children in a dual-task paradigm is related to age but not to cognition, motor behavior, injuries, or psychosocial functioning, Frontiers in Psychology, 2016, 7, s. 4-11; M. Anderson i in., Effect of age on dual-task performance in children and adults, Memory \& Cognition, 2011, 39, s. 1243-1251.

${ }^{24} \mathrm{~J}$. Ruffieux $\mathrm{i}$ in., Changes in standing and walking performance under dual-task conditions across the lifespan, Sports Medicine, 2015, 45, s. 1741, 1752.

25 J.D. Siegel, Brainstorm the power and purpose of the teenage brain, New York 2013, s. 1-6. 
nieco ponad połowę tego typu operacji arytmetycznych, a podając błędny wynik, najczęściej zaniżali cenę (zawyżali wielkość promocji). Podkreślmy raz jeszcze, że wszyscy oni odbyli pełen cykl edukacji matematycznej. To kolejny dowód na istnienie swoistego kryzysu instytucjonalnego kształtowania kompetencji matematycznych w Polsce, o którym polscy naukowcy piszą już od wielu lat ${ }^{26}$. Jaki bowiem sens ma matematyczna edukacja, skoro nie przygotowuje ona do efektywnego wykonywania codziennych obliczeń matematycznych?

Potrzebne są więc dalsze badania konfrontujące niejako efekty formalnej edukacji matematycznej z realnym życiem, z codziennymi operacjami mentalnymi, których poprawność wykonania determinuje w pewnym sensie jakość naszej partycypacji w społecznym życiu i jak widać, także to, w jakim stopniu społeczny marketing potrafi zwieść naszą percepcję.

Podziękowania. Dziękujemy Profesorowi Grzegorzowi Króliczakowi, Kierownikowi Laboratorium Badania Działań i Poznania na UAM w Poznaniu, za umożliwienie skorzystania z SV-1 Smart Voice Key i programu SuperLab. Badania były realizowane w ramach grantu European Cooperation in Science and Technology: European Network on Brain Malformations (Neuro-MIG) (CA COST Action CA16118). COST jest częścią EU Framework Programme for Research and Innovation Horizon 2020. Autorzy deklarują równy wkład w organizację badań i powstanie pracy.

\section{BIBLIOGRAFIA}

Abo-Zahhad M., Ahmed S.M., Abbas S.N., A new multi-level approach to EEG based human authentication using eye blinking, Pattern Recognition Letters, 2016, 82.

Al-Yahya E., Dawes H., Smith L., Dennis A., Howells K., Cockburn J., Cognitive motor interference while walking: a systematic review and meta-analysis, Neuroscience \& Biobehavioral Reviews, 2011, 35.

Anderson M., Bucks R.S., Bayliss D.M., Della Sala S., Effect of age on dual-task performance in children and adults, Memory \& Cognition, 2011, 39.

Bakker M., De Lange F.P., Helmich R.C., Scheeringa R., Bloem B.R., Toni I., Cerebral correlates of motor imagery of normal and precision gait, Neurolmage, 2008, 41.

${ }^{26}$ Np. E. Gruszczyk-Kolczyńska, Wspomaganie rozwoju umysłowego oraz edukacja matematyczna dzieci w ostatnim roku wychowania przedszkolnego i w pierwszym roku szkolnej edukacji, Warszawa 2009; G. Rura, M. Klichowski, Kompetencje matematyczne - założone sposoby ksztattowania i dyskursy popkulturowe, [w:] Dziecko w szkolnej rzeczywistości. Założony a rzeczywisty obraz edukacji elementarnej, red. H. Sowińska, Poznań 2011, s. 213-241; M. Federowicz, M. Sitek, Raport o stanie edukacji 2010. Spoteczeństwo w drodze do wiedzy, Warszawa 2011, s. 289-347; M. Dąbrowski, E. Wiatrak, Umiejętności matematyczne trzecioklasistów, [w:] Ogólnopolskie badanie umiejętności trzecioklasistów. Raport z badania OBUT 2013, red. A. Pregler, E. Wiatrak, Warszawa 2011, s. 28-31. 
Bonato M., Priftis K., Spironelli C., Lisi M., Umilta C., Zorzi M., Dual-tasks induce awareness deficits for the contralesional hemispace, Frontiers in Human Neuroscience, 2012, 129.

Buchwald, M., Przybylski L., Króliczak G., Decoding Brain States for Planning Functional Grasps of Tools: A Functional Magnetic Resonance Imaging Multivoxel Pattern Analysis Study, Journal of the International Neuropsychological Society, FirstView, 2018.

Dąbrowski M., Wiatrak E., Umiejętności matematyczne trzecioklasistów, [w:] Ogólnopolskie badanie umiejętności trzecioklasistów. Raport z badania OBUT 2013, red. A. Pregler, E. Wiatrak, Centralna Komisja Egzaminacyjna, Warszawa 2011.

Federowicz M., Sitek M., Raport o stanie edukacji 2010. Społeczeństwo w drodze do wiedzy, Instytut Badań Edukacyjnych. Warszawa 2011.

Francis S., Lin X., Aboushoushah S., White T.P., Phillips M., Bowtell R., Constantinescu C.S., fMRI analysis of active, passive and electrically stimulated ankle dorsiflexion, NeuroImage, 2009, 44.

Fujiwara T., Liu M., Chino N., Effect of pedaling exercise on the hemiplegic lower limb, American Journal of Physical Medicine \& Rehabilitation, 2003, 82.

Gruszczyk-Kolczyńska E., Wspomaganie rozwoju umysłowego oraz edukacja matematyczna dzieci w ostatnim roku wychowania przedszkolnego i w pierwszym roku szkolnej edukacji, Wydawnictwo Edukacja Polska, Warszawa 2009.

Hagmann-von Arx P., Manicolo O., Lemola S., Grob A., Walking in school-aged children in a dual-task paradigm is related to age but not to cognition, motor behavior, injuries, or psychosocial functioning, Frontiers in Psychology, 2016, 7.

Harada T., Miyai I., Suzuki M., Kubota K., Gait capacity affects cortical activation patterns related to speed control in the elderly, Experimental Brain Research, 2009, 193.

Huda S., Rodriguez R., Lastra L., Warren M., Lacourse M.G., Cohen M.J., Cramer S.C., Cortical activation during foot movements. II. Effect of movement rate and side, Neuroreport, 2008, 19.

Iseki K., Hanakawa T., Shinozaki J., Nankaku M., Fukuyama H., Neural mechanisms involved in mental imagery and observation of gait, NeuroImage, 2008, 41.

Klichowski M., Learning in CyberParks. A theoretical and empirical study, Wydawnictwo Naukowe UAM, Poznań 2017.

Klichowski M., Króliczak G., Numbers and functional lateralization: a visual half-field and dichotic listening study in proficient bilinguals, Neuropsychologia, 2017, 100.

Króliczak G., Buchwald M., Potok W., Przybylski L., Ręczność, praksja i język: nowe spojrzenie na delikatna triade, Polskie Forum Psychologiczne, 2018, 23.

Nagamatsu L.S., Voss M., Neider M.B., Gaspar J.G., Handy T.C., Kramer A.F., Liu-Ambrose T.Y., Increased cognitive load leads to impaired mobility decisions in seniors at risk for falls, Psychology and Aging, 2011, 26.

Pothier K., Benguigui N., Kulpa R., Chavoix C., Multiple object tracking while walking: similarities and differences between young, young-old, and old-old adults, Journals of Gerontology Series B: Psychological Sciences and Social Sciences,2014, 70.

Przybyła T., Klichowski M., Does cyberspace increase young children's numerical performance? A brief overview from the perspective of cognitive neuroscience, [w:] Świat matego dziecka. Przestrzeń instytucji, cyberprzestrzeń i inne przestrzenie dzieciństwa, red. H. Krauze-Sikorska, M. Klichowski, Wydawnictwo Naukowe UAM, Poznań 2017.

Przybyła T., Klichowski M., "Cyfrowe liczby”: Przyktady narzędzi ICT stużacych ksztattowaniu kompetencji matematycznych ucznia poprzez stymulacje praksji, [w:] Psychoedukacyjne problemy młodzieży, czyli jak być świadomym wychowawca, Kuratorium Oświaty w Poznaniu, Poznań 2018. 
Rosano C., Aizenstein H., Brach J., Longenberger A., Studenski S., Newman A.B., Gait measures indicate underlying focal gray matter atrophy in the brain of older adults, Journals of Gerontology Series A-Biological Sciences and Medical Sciences, 2008, 63.

Ruffieux J., Keller M., Lauber B., Taube W., Changes in standing and walking performance under dual-task conditions across the lifespan, Sports Medicine, 2015, 45.

Rura G., Klichowski M., Kompetencje matematyczne - założone sposoby kształtowania i dyskursy popkulturowe, [w:] Dziecko w szkolnej rzeczywistości. Założony a rzeczywisty obraz edukacji elementarnej, red. H. Sowińska, Wydawnictwo Naukowe UAM, Poznań 2011.

Salabun W., Processing and spectral analysis of the raw EEG signal from the MindWave, Przegląd Elektrotechniczny, 2014, 90.

Siegel J.D., Brainstorm the power and purpose of the teenage brain, Jeremy P. Tarcher/Penguin, New York 2013.

Sun J.C.Y., Yeh K.P.C., The effects of attention monitoring with EEG biofeedback on university students' attention and self-efficacy: the case of anti-phishing instructional materials, Computers \& Education, 2017, 106.

Takeuchi N., Mori T., Suzukamo Y., Tanaka N., Izumi S.-I., Parallel processing of cognitive and physical demands in left and right prefrontal cortices during smartphone use while walking, BMC Neuroscience, 2016, 17.

Wajda D.A., Motl R.W., Sosnoff J.J., Dual task cost of walking is related to fall risk in persons with multiple sclerosis, Journal of the Neurological Sciences, 2013, 335.

Woollacott M., Shumway-Cook A., Attention and the control of posture and gait: a review of an emerging area of research, Gait \& Posture, 2002, 16.

Yamada M., Aoyama T., Okamoto K., Nagai K., Tanaka B., Takemura T., Using a smartphone while walking: a measure of dual-tasking ability as a falls risk assessment tool, Age and Ageing, 2011, 40.

Yuan P., Koppelmans V., Reuter-Lorenz P.A., De Dios Y.E., Gadd N.E., Wood S.J., Riascos R., Kofman I.S., Bloomberg J.J., Mulavara A.P., Seidler R.D., Increased brain activation for dual tasking with 70-days head-down bed rest, Frontiers in Systems Neuroscience, 2016, 10. 